\title{
Teaching English Language with the Mediation of Digital Technologies in the Context of Remote Education in Times of Pandemic
}

\author{
Marina Camargo Mincato ${ }^{1}$, Raquel Mignoni de Oliveira ${ }^{2}$, Roberto Carlos Ramos ${ }^{3}$
}

\author{
${ }^{1}$ Department of English Literature, La Salle Carmo School, Brazil \\ ${ }^{2}$ English and Portuguese Teacher, La Salle Carmo School, Brazil \\ ${ }^{3}$ Principal, La Salle Carmo School, Brazil
}

Received: 20 Aug 2021; Received in revised form: 14 Sep 2021; Accepted: 21 Sep 2021; Available online: 27 Sep 2021 (C)2021 The Author(s). Published by Infogain Publication. This is an open access article under the CC BY license (https://creativecommons.org/licenses/by/4.0/).

\begin{abstract}
The article aims to analyze the practices of teaching English language with the mediation of digital technologies in the exceptional context of remote teaching in times of COVID-19 Pandemic. Teachers, who work in Elementary School - Final Years of a private school, located in south of Brazil, participated in the study case. The questionnaire answers, available online through Google Forms tool, were categorized based on Content Analysis Technique. The main results of the study are: the flexibility to adapt to demands of remote English language teaching; the change in teachers' conceptions and in the use of digital technologies in pedagogical practice; the importance of caring for the emotional dimension and individual monitoring; continuity in the use of digital tools in the resumption of classroom classes, and the need for continuing education for teachers.
\end{abstract}

Keywords — English language teaching, Remote teaching, Digital technologies, Pandemic.

\section{INTRODUCTION}

COVID-19 pandemic, declared by the World Health Organization (WHO) on March 11, 2020, has caused impacts and changed many social practices because of social isolation. (Henrique, 2020).

In order to enable the continuity of teaching activities, Ministry of Education (MEC) promulgated provisions containing norms and measures related to educational activities during pandemic times (Brazil, 2020 $\mathrm{a}, \mathrm{b}, \mathrm{c}, \mathrm{d}, \mathrm{e}, \mathrm{f}, \mathrm{g}, \mathrm{h}, \mathrm{i})$. In the context of Basic Education, supported by regulations relating to this educational level, the educational systems, school principals and teachers were mobilized to (re)create strategies in order to assist children and adolescents outside the school environment.

Thus, the social distance, promoted by pandemic, contributed to the process of teaching to teach and learning to learn, with the support of digital technologies, to be accelerated and decentralized, reaching educational institutions responsible for this training. In this regard, what was previously a hypothetical or even rejected proposal for virtual teaching has become a reality, since the context has also hybridized in a reality/virtual reality. (Macedo, 2017).

Given this situation, the research, case study type, aims to analyze the practices of teaching English language with the mediation of digital technologies (DTs) in the exceptional context of remote education in times of pandemic COVID19.

Therefore, the study has as theoretical framework the competences and skills set out in Common National Curriculum Base, BNCC, (Brazil, 2017) and in the National Education Plan (PNE) (Brazil, 2014), which present a framework for the elaboration and guarantee of teaching and learning English language through several pedagogical practices.

Data collection was performed through a questionnaire (Lakatos; Marconi, 2003; Gil, 2019), available through Google Forms tool. For data analysis, the Content Analysis 
Technique proposed by Bardin (2011) was adopted, which categorizes the answers in thematic groups, based on the content of educators' responses. For the study, six (100\%) of the educators who teach English in Elementary School Final Years accepted to participate in the survey.

Considering these elements, the textual structure is organized in a way that, initially, the thematic focus and research methodology are contextualized. Then, the analysis and interpretation of collected data are presented. Finally, the main findings of the study will be covered.

\section{TEACHING MEDIATED BY DIGITAL TECHNOLOGIES IN THE CONTEXT OF A PANDEMIC}

In view of a pandemic scenario, changes in behavior and thoughts can be seen, especially regarding teaching and learning. Social distancing changed the process of teaching and learning as well as the use of digital technologies, which before pandemic times was seen as a hypothetical way of teaching, now became the basis for the continuity of classes. However, digital technologies, in addition to continuing education, were also responsible for its decentralization, reaching all kinds institutions (Macedo, 2017).

When analyzing National Education Plan (PNE) (Brazil, 2014), it already presented digital technologies as strategies to improve the national results of Brazilian Educational Development Index (IDEB) (Brazil, 2007), showing that the recognition of this resource in the field of education is not as recent as imagined, highlighting the following strategies:

"7.6 Select, certify and disseminate educational technologies for primary and secondary education, ensuring the diversity of pedagogical methods and proposals, as well as monitoring the results in the education systems in which they are applied.

7.7 Encourage the development of educational technologies and innovation of pedagogical practices in education systems, which ensure the improvement of the school flow and student learning.

7.11 Provide digital and technological equipment and resources for pedagogical use in the school environment to all elementary and high schools." (Brazil, 2007).

Therefore, educational possibilities that digital technologies open for teaching practice as mediators of the teaching and learning processes are undeniable. However, it is necessary to draw attention to the fact that their use in the classroom requires a break from being a teacher who changes from being the center of knowledge to a facilitator of learning processes (Bacich; Moran, 2018).

Besides PNE (Brazil, 2014) addresses the use of DTs as a positive resource to be explored by teachers, BNCC (Brazil, 2017) also enhances them as a teaching strategy, ensuring the general competence of the Base, field of digital culture, which should:

"Understand, use and create digital information
and communication technologies in a critical,
meaningful, reflective and ethical way in several
social practices (including school) to
communicate, access and disseminate
information, produce knowledge, solve problems
and exercise prominence and authorship in life
personal and collective." (Brazil, 2017: 11).

In this perspective, the remaining question is: why digital technologies have spread with greater intensity only in this pandemic context, since they were so little explored before, even though it is a mandatory competence to be developed, according to BNCC (Brazil, 2017), and a potential resource according to PNE (Brazil, 2014)? About this questioning, it can be said that continuing education of teachers and the need to use these tools were the precursors for the engagement of digital technologies in schools during remote teaching.

It was noticed that many educators, before pandemic, did not use digital technologies in educational practice, as they did not know them or did not know how to insert them in their lesson planning, as it requires a change in teaching practices and student attitude to adhere to them. However, with the advance of COVID-19, educational institutions had to provide training to teachers who began to understand this mediation process, integrating digital technology into their pedagogical practices, as there was an emerging need: the continuation of classes, even if remote.

It is important to highlight that digital technologies have always been essential for educational practices, as expressed in the documents BNCC and PNE; nonetheless, when used as mediators, they are imbricated in the processes of teaching and learning. When only conceived as technological devices, used for didactic transposition of traditional teaching (understood here as teacher-centered teaching, without the student being active in the learning process), they do not contribute as much, since the student does not feel engaged and is not the protagonist of his own learning, he is just a reproducer of what is addressed to him. 
Furthermore, it can be stated that DTs have been recognized by the analyzed documents as a way of promoting teaching and learning. Before pandemic, it was a slow walk, as there was not much engagement on the part of teachers, nor training that would support them to adopt these resources in classes. Then, with the advent of COVID-19 pandemic, schools were forced to provide training movements and teachers to learn to teach in the face of the unknown.

Taking this educational journey as a reference, it is expected that we will move towards a scenario of major disruptions in terms of future education. After all, digital technology by itself does not support quality teaching, as it needs to be seen as a path of profound transformation in education when it substantially modifies the imbricated subjects, as well as the way they relate to the learning object (Coll; Monereo, 2010).

\section{ENGLISH LANGUAGE TEACHING AT SCHOOL}

The teaching of English language, due to its relevance to global communication, figures as an influential language of prestige and relevance in the school environment. Communicating in English is also about maximizing the possibilities of being connected to world events and assuming the identity of a global citizen, permeating different cultures and appropriating intercultural elements.

Regarding this background, BNCC (Brazil, 2017) defines additional language teaching as mandatory from the sixth year of Elementary School onwards. This means that, in any school in the country, from this stage on, English language teaching must be ensured in the curriculum.

As stated by the promulgation of the document, the choice of English as an additional language is justified by its role in world communication. The lingua franca is used by speakers across the globe, with the most varied linguistic and cultural repertoires. According to data from Linguistic Treasure of Federal University of Pelotas (UFPEL) (2021), the language covers $1,132,366,680$ speakers, surpassing the $1,116,596,640$ speakers of Chinese-Mandarin.

In this perspective, teaching an additional language means, according to BNCC (Brazil, 2017), to present the vast world that is configured, highlighting the traits of diversity, which lay foundations in the classroom itself and extend to all public spaces of social life. Thus, there is an opportunity for a reflection on themselves, as an individual and on their conditions through encountering the other, understanding their singular self as well as the plural world in which they live. In this meeting, the student is given the opportunity to contrast intercultural elements of their own culture, along with the proposal to identify values attributed to other cultures in the society in which they live.

BNCC (Brazil, 2017: 241) maintains that:
"Learning English Language enables the creation of new forms of engagement and participation of students in an increasingly globalized and plural social world, in which the borders between countries and personal, local, regional, national and transnational interests are increasingly blurred and contradictory. Thus, the study of English language can provide everyone with access to the linguistic knowledge necessary for engagement and participation, contributing to the critical agency of students and the exercise of active citizenship, in addition to expanding the possibilities of interaction and mobility, opening new paths construction of knowledge and continuity in studies. It is this formative character that inscribes English learning in a conscious and critical perspective of linguistic education, in which pedagogical and political dimensions are intrinsically linked."

Teaching an additional language provides the students an encounter with diversity, leading them to deal with the different and the new, making the space of the additional language in the curriculum a space for citizenship shaping. According to Schlatter and Garcez (2012: 37-38):

"The additional language class can be a space for its participants to discover a new form of human expression, with views of the world that are different from their own, with a language that can fascinate or frighten. And this space should inspire, above all, for reflection and information on the local and immediate realities of students in interlocution tasks with the world that takes place in that other language. [...] In the additional language class, the student can see, from the beginning and each time more, his enlarged world and thus decide what matters in these new horizons for his life, in his immediate world, empowering himself to participate more assertively in his own world and in the larger world that he presents in his life as a citizen."

As claimed by this perspective, La Salle Carmo School verifies the importance of offering English language not only in the Final Years stage, but starting in Kindergarten as a means to promote quality language teaching within the curriculum.

In 2021, Early Childhood Education has three periods of English a week in the curriculum, followed by two weekly 
periods in Elementary School - Initial Years and four weekly periods in Elementary School - Final Years. This schedule of extended workload is in line with the contributions of BNCC (Brazil, 2017) in terms of comprehensive education, emphasizing that learning an additional language encompasses much more than the improvement of language skills, inviting for working interdisciplinary, favoring the educational process in its essence in which,

"Basic Education should aim at training and
global human development, which implies
understanding the complexity and non-linearity of
this development, breaking with reductionist
views that privilege either the intellectual
(cognitive) or the affective dimension. It also
means assuming a plural, singular and integral
vision of children, adolescents, young people and
adults-considering them as subjects of learning -
and promoting an education aimed at their
acceptance, recognition and full development, in
their singularities and diversities." (Brazil,
2017:14).

In consequence, teaching English at school is conceived as a catalyst for unveiling the social world, bringing the students closer to language to access this pluralized universe. It is about the opportunity to create their own codes that reach bigger perspectives. In these circumstances, the individual develops entirely, being open to live with diversity multiple experiences, identifying himself as a citizen, either in his immediate space, or as a member of a group living collectively.

\section{METHODOLOGICAL APPROACH}

This research is configured as a study case (Yin, 2001) and has as an investigative focus the use of digital technologies in teaching English in Elementary School - Final Years in front of remote education. As suggested by Yin (2001), in carrying out a study case, it is essential to use several data collection instruments, with a view to triangulation of information obtained through different sources.

As an object of study to initiate reflections and discussions on the topic to be explored, six teachers who teach the curricular component of English to classes from sixty to ninth grade of Elementary School - Final Years, during the year 2020, accepted to answer the research. The age range is between 26 and 52 years old. All are graduates and three of them $(50 \%)$ reported having attended a Latu Sensu Postgraduation course. Regarding teaching time, all teachers work between one and 10 years. Regarding the weekly schedule, all respondents work between 14 and 40 hours per week and only one teacher had taught English classes in online format before the pandemic.

The reflections presented arise from the following questions asked to the educators and which guided the investigation: What are the positive and negative aspects of remote teaching in English language classes? How was student's engagement in remote classes? Which digital technologies were used as a pedagogical strategy? What were the pedagogical practices adopted in remote teaching English Language subject? What are the perspectives of the use of digital technologies in the resumption of classroom classes?

Data was collected through a questionnaire available on Google Forms, observing the ethical aspects of research. For data analysis, the Content Analysis Technique proposed by Bardin (2011) was adopted. Next, the research scenario was contextualized.

\section{THE RESEARCH CONTEXT}

The research context is the teaching of English language, therefore, an attempt was made to broaden it so that it could have different reports of experiences on the use of digital technologies in remote education during this period of COVID-19 pandemic.

As an investigative setting, there is La Salle Carmo School, which is located in south of Brazil, and belongs to a private education chain. It offers all stages of Basic Education, conceiving students from families belonging to middle and upper classes. Thus, it is a school context in which students have access to digital teaching technologies, electronic devices and internet connection.

For remote learning, school adopted a content management system on the digital platform Google Classroom (paid version). Furthermore, with this management system, the teachers adopted other tools, applications and digital technological resources they considered appropriate for the development of competences provided for English language study plans.

Regarding the organization of English language subject at school, in 2021, Early Childhood Education has three weekly periods in the curriculum, followed by two weekly periods in Elementary School - Initial Years and four weekly periods in Elementary School - Final Years. Students use Cambridge University Press teaching materials and classes aim to develop the four essential skills: reading, writing, listening and communicative practice. At the end of ninth year of Elementary School Final Years, students have the possibility of applying for international Cambridge exams, certifying their proficiency. 
In view of research context, it is important to emphasize that researchers are directly involved with teaching English in regular education in Elementary School - Final Years, in pedagogical management and in the training of English Language teachers, which is why they maintain direct contact with teachers and where data collection is collected, as well as the involvement of researchers in the study.

\section{DESCRIPTION AND ANALYSIS OF DATA}

Regarding the proposals of Content Analysis Technique (Bardin, 2011), the focus of this section is the presentation and reflection on the collected data, which are arranged in sequence, in four thematic categories. In order to establish a pattern, the following name was used: $\mathrm{T}$ (for teacher), followed by the number of the questionnaire which represents the order of data collection.

\subsection{Category $I$ - Positive and negative aspects of remote teaching in the English Language subject}

This thematic category seeks to examine recurrent ideas in the responses of teachers, in which positive aspects about remote teaching stand out, such as the use of technological resources in teaching and learning processes, adopted methodologies, experience exchanges between teachers, classes interaction, teacher training and greater student autonomy.

The following fragments contextualize some of the mentioned aspects relating to the positive aspects of remote English language teaching:

"Use of technological resources; support from colleagues through exchange of experiences among teachers; use of new teaching methodologies; new challenges and new experiences." (T1).

"Resources appeared during the classes and also with the training of teachers, making the classes more attractive. The affection of students and school staff was the most brilliant and encouraging aspect." (T2)

"The discovery of countless tools, applications, websites, online games and others... was to discover and get to know the work of teachers from all over the world and to be able to share and share knowledge." (T3).

Through the synthesis of responses from the set of respondents and the fragments presented, it appears that the group of teachers considered the use of digital technologies as essential in remote classes, especially conceiving the possibility of exchange between fellow teachers around the world. Such positions corroborate the statements of Bacich; Moran (2018), who claim that Education takes place through the connection between peers, the network and the world.

Another significant aspect for teachers was the learning of new digital technological tools and pedagogical strategies. In this period of pandemic, teachers had to reinvent and relearn, changing their attitude towards teaching and learning, seeking new ways to ensure quality education, achieving what is proposed by BNCC: “(...) Educational technologies in pedagogical practices in education systems ensure the improvement of school flow and student learning." (Brazil, 2017:77).

In this context, digital technologies provided this reinvention in pedagogical practices, because there were moments of training that provided this development, urging teachers to change their attitude. Moreira and Schlemmer (2020: 28) corroborate: "it is necessary to trigger educational processes aimed at improving and developing the professional quality of teachers". Still in this perspective, Levy (1999) says that teachers are in a context that were involved and challenged to use technology, this shows the growing number of them who have combined DTs with pedagogical practice.

On the other hand, in teachers' statements, answers are found that emphasize some difficulties experienced in this context of remote learning, such as "having to adapt quickly to a new teaching methodology" (T1), "little interaction between students and monitoring learning" (T2), "the loss of oral culture of the English language, adaptation in a short period of time to this teaching model," (T3) and the "challenge of giving greater support to students with difficulties of learning." (T5). 
These statements demonstrate that just incorporating technological resources does not remodel educational processes, although, "[...] it substantially modifies the context in which these processes occur and the relationships between their actors and the tasks and learning content, thus opening up, the path to an eventual deep transformation of these processes." (Coll; Monereo, 2010: 11). The weakness is precisely to encourage students to participate, awakening their autonomy, because, despite being digital natives, they are not used to being protagonists in the processes of teaching and learning and using certain digital tools. In this sense, the teacher's mediation is more than important, it is essential for the student to be active while learning.

However, Barreto and Rocha (2020) highlight how much teachers reinvent themselves in the pandemic period: even without adequate preparation, there is a relentless search to offer the best to their students so that they are not left unattended and could develop their skills and abilities necessary autonomously. In this horizon, the role of the teacher as a mediator stands out, seeking to encourage students to provide quality education even in the remote mode.

\subsection{Category II - Student engagement in remote classes}

BNCC (Brazil, 2017) challenges teachers in teaching and learning processes regarding the development of skills related to the use of digital technologies, resources and languages, since, with COVID-19 pandemic there was a need for remote learning, leading to an acceleration of this digital movement. Digital technologies at school were being adopted slowly and progressively, but with the change from the traditional pattern of the classroom to remote education, because of social isolation, they had to be applied immediately, which impacted the dimension of adults and children.

The emotional dimension is portrayed by teachers, who noticed a reduction in engagement, participation and motivation of students in remote classes. The most common aspects are:

"Participation of students from Elementary School 2 is very low. There were few who actually participated.” (T1).

"Due to the fact that they didn't turn on the camera and also, very few, turned on the microphone for a more complete interaction, this participation was very difficult. But over time, some stand out and classes follow the planned course." (T2).
"Some were very motivated, but most did not attend classes.” (T4).

"Student participation, motivation and engagement dropped dramatically. From the reports of fellow professors from other disciplines, I see that this is a general issue, not specific to English." (T5).

According to the background designed by teachers during the remote classes, it was necessary to develop a series of skills and abilities, in addition to a quick adaptation and learning of new methodologies, that is, new ways of communicating and interacting through digital means. This new class pattern has reached the behavior and emotional dimension of students, changing their interaction, motivation and engagement.

Given this situation, (T3) presents ways to teach classes, fostering self-esteem and student participation in remote English lessons. 
"Every morning the class started with music, a phrase - a reflection. I tried to bring joy and happiness to my classes. I feel that we are in serious trouble from pandemic and it is up to us teachers to bring some spiritual peace, joy and love to our students. In this way, I feel all the time that the students are very engaged... except for some who go through psychological issues. But in general, I feel the students are happy and engaged in English classes. I try to diversify my activities a lot. I know that for learning to take place, we need the students' attention first, and for students to be attentive, they need to like it... That is why diversified classes to attract all students, attract all the different ways of learning. Myth is to think that there is only one method and that there will be student engagement when they are exposed to repetitive and non-challenging tasks." (T3)

This teacher's testimony corroborates Moran's idea, which emphasizes:

"In education, the most important thing is not to use large resources, but to develop favorable communicative and affective attitudes and some negotiation strategies with students, reach an agreement on research activities and how to present them to the class. (Moran, 2007: 31)

This shows that the teacher must have clear objectives when planning the classes, seeking to instigate their students, with digital technologies being the facilitator to develop the activity in practice.

Therefore, BNCC (Brazil, 2017) provides the educational commitment of teachers to the full development of students, through promotion of skills, highlighting the socio-emotional skills, character and attitudes of the person. In this scenario of inclusion of socio-emotional skills, the role of the educator stands out, as he is the mediator, acting in front line of these skills to be developed in the educational praxis.

The teacher deals with the impact of emotions and must be aware of this in the pedagogical process, as emotion interferes with information retention process. It takes motivation to learn and attention is essential in learning. Therefore, it is necessary to reflect on the teaching praxis in an intentional format that seeks to develop these skills both in the teacher and the student. (Morais, 2020).

\subsection{Category III - digital technologies as a pedagogical strategy for English teaching}

This thematic category will present digital tools used as a pedagogical strategy in the teaching of English in the context of remote education, followed by a brief reflection on the changes generated by them in teaching-learning.

Regarding the digital technologies adopted by teachers during English language classes, as reported by them, there are the tools: Google Classroom, lives, worksheets for extra activities, Google Forms, Google Docs, Google Slides, Jamboard, Kahn Academy, Youtube, EscapeRoom, Baamboozle Games Online, recordings, Quizlet, EnglishVid and softwares to create Podcasts.

It is noticed that, by adopting digital technologies, teachers gave new meaning to their educational practices, conceiving that remote teaching required other ways of teaching, using various digital teaching strategies and instruments. According to PNE (Brazil, 2014), students must be in contact with digital technologies so that they can understand, use and create technologies in a critical, meaningful and ethical way in order to access information, produce knowledge and solve problems. Furthermore, the tools used by teachers make it possible to verify that remote teaching required other ways of teaching, using different strategies and digital teaching instruments.

The re-adaptation of reality from the physical classroom to the virtual one brought changes beyond language, changing the way students and teachers interact. Considering this context, digital technologies present themselves as mediators to develop new pedagogical practices, and their importance will be in the way the teacher will use the resources and not only in their simple use. For Weinert (2013: 26), "in this challenge of making teaching and learning pleasant and effective moments, the teacher has a fundamental role, as it is up to him to motivate and demonstrate that it is possible to have a correlation between educational content and reality of the student".

Still, regarding the use of digital technologies, Dotta et al. (2013) warns that technology allows great access to information, since, by itself, it does not promote learning conditions for those who have access to it. At this juncture, he states that education professionals have a very important role in this scenario, in which, in order to work on technologies, the person must master the technique and have the necessary planning.

\subsection{Category IV - Practices adopted in English Language subject during remote teaching and continuity in face-to-face classes}

The educational practices developed during remote teaching by English language subject point to the future of 
education, which already seems to never be the same again, given the adoption of digital technologies to continue teaching and learning processes. This is evident in the speech of $(\mathrm{T} 1)$ :

"The door to learning that takes place in different ways has been opened. I believe that after the pandemic, even in a complementary way, it will no longer be closed. In other words, all virtual resources, fortunately or unfortunately, are here to stay. All practices with the use of technological resources will be maintained. Particularly, I believe that Google Forms is an excellent tool for assessments as long as it is performed $100 \%$ in person."

In addition to digital technologies, (T5) points to the hybrid model as a teaching strategy:

"Although Google Forms is a great tool for testing, I believe students still need to have contact with the print version, writing on paper. I would still use this tool, but not for all evaluation activities. Of course, online games are a resource that I will continue to use - I used them before too, but I hope that soon we will be able to make other types of games that promote interaction between students and facilitate learning, but without this 'stick' of online activity. That we can have room disputes between groups and pairs and that we can meet in the school yard."

These speeches refer to a mix between digital and traditional. What has already been done is not abandoned, but what has been done through DTs is not denied. Likewise, it is believed that the key to future lies in the balance of using one or the other, or both at the same time, since what will determine this is the teacher's objective regarding the particular activity.

In this context, it is noticed that remote teaching contributed to teachers continuing the use of DTs, as exemplified in the speech of (T6): "I use technological tools to build activities, such as "slides and online games.". (T2) corroborates: "Students really like being able to compete, so the games are super encouraged and we learn without too much stress.

In this case,

"This is not about using technologies at any cost, but about consciously and deliberately following a change in civilization that profoundly questions the institutional forms, mentalities and culture of traditional educational systems and, above all, the roles of teacher and student (Lévy, 2005: 172).
It is clarified, thus, that using digital technology only as support for some specific activities, as there is no break in the way the teacher and the student see themselves in the teaching and learning processes, does not qualify the educational practice; it only reinforces already imposed standards. The use of DTs in the classroom, whether physical or digital, implies in the process of mediation of knowledge so that the student takes the lead and the teacher is the teaching facilitator.

Finally, (T3) makes a self-criticism of the traditional teaching model and emphasizes the importance of teacher training on digital technologies:

"I feel that it takes time to innovate and all this learning I will carry with me to all my classes, whether they are remote or not. I'm very happy with what the school has been offering us in terms of training courses, etc. and as I'm curious, I look for many ideas outside the school environment. All this will be maintained, of course, in moderation and depending on the activities proposed in the classroom."

This statement reflects that the focus should be on training these teachers and not on the overvaluation of educational technologies, as without the mediation of the teacher, they are not capable of guaranteeing quality education.

It is important to highlight that, in this digital context, the teacher will not be replaced by the intensification of the use of DTs, but will be even more valued, as it will be the facilitator of knowledge. Thus, it is understood that it is necessary to rescue the teaching work and bring it to the focus of public policy concerns and DTs should be reduced, therefore, to the condition of mediator in the teaching of English, given the proper training to teachers so they know what to do with them.

\section{FINAL CONSIDERATIONS}

The essential basis of reflections presented throughout the article are the teaching practices of English language teaching with the mediation of digital technologies applying the study in the exceptional context of remote education in times of the COVID-19 Pandemic and getting it wider to a hybrid teaching in the future.

According to the teachers, the use of digital technologies in teaching English language, when combined with the teaching performance, can boost student learning, linked to teacher training, conceiving the emotional dimension of students as well as the importance of engaging the students.

About the limitations of the study, it highlights the difficulties of the teachers in engaging students, eliciting 
motivation as well as the use of digital tools and access to platforms, network connection, devices and the lack of previous knowledge in terms of remote teaching.

When it comes to advantages, the study made it possible to identify aspects such as: a) flexibility to adapt to the demands of remote English language teaching; b) change in teachers; conceptions and the use of digital technologies in pedagogical practice; c) importance of caring for the emotional dimension and individual monitoring of each student; d); continuity in the use of digital tools in the resumption of in-person classes and, e) the need for continuing education for teachers. This set of aspects, somehow, interfered in the remote teaching of English language and reverberated the importance of digital technologies in the teaching and learning processes of students.

\section{REFERENCES}

[1] Bacich L., Moran J. (2018). Metodologias Ativas para uma Educação Inovadora: Uma Abordagem Teórico-Prática. Porto Alegre: Penso.

[2] Bardin, L. (2011). Análise de Conteúdo. São Paulo: Editions 70.

[3] Barreto, A. C. F., Rocha, D. N. (2020). COVID 19 e Educação: Resistências, Desafios e (Im)Possibilidades. Revista Encantar - Educação, Cultura e Sociedade. Bom Jesus da Lapa, v. 2. http://www.revistas.uneb.br/index.php/encantar/article/vie w/8480. Access on: 28 jul. 2021.

[4] Brazil. (2020). Diretrizes Curriculares Nacionais para a oferta de Educação Plurilíngue. Conselho Nacional de Educação/Câmara de Educação Básica. PARECER CNE/CEB N: 2/2020. Brasília-DF.

[5] Brazil. (2007). Índice de Desenvolvimento da Educação Básica (IDEB). Brasília, DF.

[6] Brazil. (2017). Ministério da Educação. Base Nacional Comum Curricular. Brasília: MEC.

[7] Brazil. (2020a). Ministério da Educação. Conselho Nacional de Educação.. Brasília-DF.

[8] Brazil. (2020b). Ministério da Educação. Conselho Nacional de Educação. Parecer CNE/CP n ${ }^{\circ}$ 10/2020, approved on June 16th. Brasília-DF.

[9] Brazil. (2020c). Ministério da Educação. Conselho Nacional de Educação. Parecer CNE/CP n ${ }^{\circ}$ 11/2020, approved on July 7 th. Brasília-DF.

[10] BRAZIL. (2020d). Ministério da Educação. Conselho Nacional de Educação. Parecer CNE/CP n ${ }^{\circ}$ 15/2020, approved on October 6th. Brasília-DF.

[11] BRAZIL (2020e). Ministério da Educação. Conselho Nacional de Educação. Parecer CNE/CP n ${ }^{\circ}$ 16/2020, approved on October 9th. Brasília-DF.

[12] BRAZIL. (2020f) Ministério da Educação. Conselho Nacional de Educação. Parecer CNE/CP n ${ }^{\circ}$ 19/2020, approved on December 8th. Brasília-DF.
[13] Brazil. (2020g). Ministério da Educação. Conselho Nacional de Educação. Resolução CNE/CP n 2, de 10 de dezembro. Brasília-DF.

[14] Brazil. (2014). Plano Nacional de Educação. MEC. Brasília.

[15] Coll, C., Monereo, C. (2010). Educação e Aprendizagem no século XXI: novas ferramentas, novos cenários, novas finalidades. In: ColL, C., Monereo, C. (org.). Psicologia da educação virtual: aprender e ensinar com as tecnologias da informação e da comunicação. Porto Alegre: Artmed.

[16] Dotta, S. C. [et al]. (2013). Abordagem dialógica para a condução de aulas síncronas em uma webconferência. In: X Congresso Brasileiro de Ensino Superior a Distância, 2013, Belém. Anais do X Congresso Brasileiro de Ensino Superior a Distância. Belém: Unirede/UFPA.

[17] Fundação Carlos Chagas. (2020). Educação escolar em tempos de pandemia. Informe n. 1. https://www.fcc.org.br/fcc/educacao-pesquisa/educacaoescolar-em-tempos-de-pandemia-informe-n-1.

[18] Gil, A. C. (2019). Métodos e técnicas de pesquisa social. 7. ed. São Paulo: Atlas.

[19] Henrique, T. (2020). COVID-19 e a internet (ou estou em isolamento social físico). Interfaces Científicas - Humanas e Sociais, Aracaju, v. 8, n.3, p. 173-176. https://periodicos.set.edu.br/humanas/article/view/8713/393 .

[20] Lakatos, E. M., Marconi, M. A. (2003). Técnicas de pesquisa: planejamento e execução de pesquisas, amostragens e técnicas de pesquisa, elaboração, análise e interpretação dos dados. 5. ed. São Paulo: Atlas.

[21] Lévy, P. (1999). Cibercultura. São Paulo: Editora 34.

[22] Macedo, A. R. M. (2017). Abordagem Híbrida na Formação Inicial de Professores de Inglês: Integrando as Novas Tecnologias. Thesis (Masters in Linguistics), Universidade Federal do Espírito Santo, Vitória.

[23] Moran, J. M. (2007). A educação que desejamos:novos desafios e como chegar lá.Campinas: Papirus.

[24] Santos Júnior, V. B., Monteiro, J. C. S. (2020). Educação e COVID-19: as tecnologias digitais mediando a aprendizagem em tempos de pandemia. Revista Encantar Educação, Cultura e Sociedade - Bom Jesus da Lapa, v. 2, p. 01-15, jan./dec.

[25] Schlatter, M., Garcez, P. M. (2012). Línguas adicionais na escola: aprendizagens colaborativas em inglês. Erechim: Edelbra, 2012.

[26] Tardif, M. (2002). Saberes docentes e formação profissional. Petrópolis, RJ: Vozes.

[27] Universidade Federal De Pelotas. (2021). O que a imigração tem a ver com a língua? In Tesouro a Descobrir. Linguas de Heranças. 08 mar. https://wp.ufpel.edu.br/tesouro-linguistico/page/2/

[28] Yin, R. (2001). Estudo de caso: planejamento e método. 2. ed. Porto Alegre: Bookman. 